\title{
Effects of diadenosine polyphosphates and seminal fluid vesicles on rabbit sperm cells
}

\author{
A. Minelli ${ }^{1}$, L. Liguori ${ }^{1}$, I. Bellezza ${ }^{1}$, T. Renieri ${ }^{2}$ and C. Castellini ${ }^{3}$ \\ ${ }^{1}$ Dipartimento di Scienze Biochimiche e Biotecnologie Molecolari, Sezione di Biochimica Cellulare, \\ Università di Perugia, via del Giochetto, 06126 Perugia, Italia; ${ }^{2}$ Dipartimento di Pediatria, \\ Ostetricia e Medicina della Riproduzione, Sezione Biologia, Università degli Studi \\ di Siena, via Pendola 62, 53100 Siena, Italy; and ${ }^{3}$ Dipartimento di Scienze \\ Zootecniche, Università di Perugia, Borgo XX Giugno, 06123 Perugia, Italia
}

\begin{abstract}
Membrane vesicles were isolated from rabbit seminal plasma. Electron microscopy analyses showed the presence of numerous small, round vesicles with a diameter of about $70 \mathrm{~nm}$. Determination of enzyme activities was carried out by high performance liquid chromatography and showed that the vesicles can degrade the diadenosine polyphosphates (ApnA), Ap3A and Ap4A and ATP and ADP, but not AMP. Studies of the degradation of diadenosine compounds by the vesicles present in seminal fluid showed an increasing production of AMP as the by-product and a time-dependent generation of dephosphorylated products consistent with the presence of ecto-ATP diphosphophosphatase (ecto-apyrase). In the presence of rabbit spermatozoa, AMP did not accumulate because 5'nucleotidase and adenosine deaminase, present at the surface of sperm cells, transformed AMP into adenosine and inosine. The effects of seminal fluid vesicles and diadenosine compounds on the
\end{abstract}

acquisition of fertilizing capacity by rabbit spermatozoa were evaluated by Pisum sativum agglutinin fluorescein isothiocyanate conjugated staining. The results obtained with uncapacitated spermatozoa showed that the capacitating effector BSA could be substituted efficiently by the addition of diadenosine compounds and vesicles previously incubated for $2 \mathrm{~h}$ to the capacitative medium. Under these experimental conditions, the spontaneous acrosome reaction rate was not increased. Capacitated rabbit spermatozoa did not undergo acrosome reaction when L$\alpha$-lysophosphatidylcholine was substituted by diadenosine compounds previously incubated with vesicles. In conclusion, this study has shown that rabbit seminal fluid vesicles can degrade diadenosine compounds to AMP and that the addition of the vesicles and diadenosine compounds to uncapacitated rabbit spermatozoa favours the acquisition of the fertilizing capacity.

\section{Introduction}

Membrane vesicles have been identified in the seminal plasma of several mammals (Davis, 1973; Breitbart and Rubinstain, 1982; Ronquist and Brody, 1985; Fornes et al., 1991). These vesicles are secreted from different accessory organs of the reproductive system and are named after the organ that produces them. Prostasomes were identified in human semen samples (Ronquist and Brody, 1985), prostasome-like vesicles in horse seminal plasma (Minelli et al., 1998), vesiculosomes in bovine seminal plasma (Agrawal and Vanha-Pertulla, 1987), and membrane organelles of epididymal origin in rabbit, ram and rat semen samples (Davis, 1973; Breitbart and Rubinstain, 1982; Fornes et al., 1991). These extracellular vesicles are involved in several physiological activities, such as immunosuppressive (Kelly, 1995; Nilsson et al., 1998), antibacterial (Carlsson et al., 2000a) and growth-inhibitory (Carlsson et al.,

Email: albaminelli@virgilio.it 2000b) effects and enhancement of sperm motility (Wang etal., 2001). Different proteins and enzymes form part of the mosaic membrane of the vesicles (Ronquist et al., 1978a,b, 1988; Olsson and Ronquist, 1990; Fabiani and Ronquist, 1995; Arienti et al., 1997), but their functional role and importance has not yet been completely assessed. Diadenosine polyphosphates (ApnA, $n=2-6$ ) are natural ubiquitous compounds identified in biological systems by Randerath et al. (1966) and have since been studied extensively in prokaryotic and eukaryotic organisms. Several important signalling functions, both intracellular and extracellular, have been ascribed to the diadenosine compounds (McLennan, 1992; Kisselev et al., 1998; Miras Portugal et al., 1998; Pintor et al., 2002). The ultimate fate of cell lineages and the survival of an organism seem to depend upon the strict control of the cellular diadenosine polyphosphate metabolism carried out by hydrolytic enzymes belonging to the Nudix family (Cartwright and McLennan, 1999; Ingram et al., 1999; Safrany et al., 1999). Extracellular diadenosine polyphosphates have been identified as 
neurotrasmitters and vasomodulators (Miras Portugal et al., 1998). Binding sites for diadenosine polyphosphates have been shown in cells of organs such as heart (Walker et al., 1993), brain (Rodriguez Pascual et al., 1997; Jimenez et al., 1998) and liver (Edgecombe et al., 1996), and in insulin-secreting cells (Verspohl and Johannwille, 1998) and cultured vascular smooth muscle cells and endothelium cells (Verspohl et al., 1999).

ApnA can act through P1 and P2 purine receptors (Miras Portugal et al., 1999). ApnA are antagonists for P2X1 receptors in the vas deferens (Hoyle et al., 1997), act as allosteric effectors for oocytes expressing neuronal P2X2 (Pintor et al., 1996) and act on P2Y metabotrophic receptors in endothelial cells (Mateo et al., 1996). Physiological cell and tissue responses to extracellular ApnA are controlled by ecto-diadenosine polyphosphates hydrolases, which are capable of terminating ApnA signalling. The ecto-enzyme produces nucleotides, which are further degraded via the ecto-nucleotidase cascade (Zimmerman, 1996a). Ecto-enzymes that are able to inactivate ApnA have been found in aortic endothelial cells (Goldman et al., 1986; Ogilvie et al., 1989), chromaffin cells (Rodriguez Pascual et al., 1992) and adrenomedullary vascular endothelial cells (Mateo et al., 1997). The developing hypothesis attributing roles as extracellular signalling nucleotides to ApnA, their influence on motility of human spermatozoa (Chan et al., 1991), and the recent discovery of diadenosine polyphosphates hydrolase activity on the surface of human prostasomes (Minelli et al., 2002) has led this investigation of whether rabbit seminal fluid vesicles contain this ecto-enzyme and whether diadenosine polyphosphates have a role in the physiological functions of rabbit spermatozoa. The present study reports the isolation of seminal fluid vesicles in rabbit ejaculates and the identification of an ecto-apyrase capable of hydrolysing diadenosine polyphosphate at their surface. The effects of the addition of vesicles and diadenosine polyphosphates on rabbit spermatozoa were investigated in an attempt to determine how they affect the acquisition of fertilizing capacity by rabbit sperm cells.

\section{Materials and Methods}

\section{Materials}

Unless otherwise stated, all the reagents and dinucleotide polyphosphates were obtained from Sigma (St Louis, MO). High performance liquid chromatography (HPLC) solvents and RC $0.2 \mu \mathrm{m}$ filters were obtained from Corning Incorporated (Corning, NY). Sephadex G-200 and PD-10 were from Pharmacia (Uppsala). The protein assay kit was from Bio-Rad (Hercules, CA).

\section{Preparation of rabbit seminal vesicles}

Seminal fluid vesicles were isolated from ejaculated rabbit semen obtained using an artificial vagina from
10 bucks (aged 6-10 months, NZW Breed) reared at the Animal Science Department of Perugia University. Pooled ejaculates were centrifuged at $500 \boldsymbol{g}$ for $5 \mathrm{~min}$ at $4^{\circ} \mathrm{C}$ to pellet spermatozoa. The seminal plasma was then centrifuged at $10000 \mathrm{~g}$ for $10 \mathrm{~min}$ at room temperature $\left(20^{\circ} \mathrm{C}\right)$ to eliminate cell debris and the supernatant was centrifuged at $105000 \mathrm{~g}$ for $2 \mathrm{~h}$ at $4^{\circ} \mathrm{C}$. The pellet containing vesicles, amorphous material and lipid droplets was suspended in $30 \mathrm{mmol}$ Tris- $-\mathrm{HCl} \mathrm{I}^{-1}$ and $130 \mathrm{mmol} \mathrm{NaCl} \mathrm{I-1}$, pH 7.6 (buffer A). The suspension was first subjected to chromatography on a PD-10 column (Pharmacia, Uppsala) to remove most of the lipid droplets. The vesicles were then purified by chromatography on a Sephadex G-200 column $(1.5 \mathrm{~cm} \times$ $30.0 \mathrm{~cm}$ ) pre-equilibrated with buffer $A$. Fractions were examined for absorbance at $280 \mathrm{~nm}$ before being pooled and then centrifuged at $105000 \mathrm{~g}$ for $2 \mathrm{~h}$. The pellet was suspended in buffer $\mathrm{A}$ and stored at $-196^{\circ} \mathrm{C}$ until use. Protein concentration in the vesicle samples was determined by Bio-Rad protein assay kit (BioRad).

\section{Electron microscopy}

Rabbit seminal fluid vesicles, isolated as described above, were fixed for $2 \mathrm{~h}$ at $5^{\circ} \mathrm{C}$ in Karnovsky fixative and post-fixed with $1 \%(\mathrm{w} / \mathrm{v}) \mathrm{OsO}_{4}$ in $0.1 \mathrm{~mol}$ cacodylate buffer $\mathrm{I}^{-1}, \mathrm{pH}$ 7.2. The pellet was then dehydrated and embedded in pure epon-araldite resin. Ultrathin sections were obtained with Reichert-Jung Super Nova ultramicrotome (Wien) and observed by Philips CM10 (Eindhoven).

\section{HPLC}

Analyses were performed with a Perkin-Elmer HPLC Model 250-Series 10 equipped with a LC90J absorbance detector and a LC100 integrator (Perkin-Elmer, PE Nelson Division, San Jose, CA) using a Water ODS2 $(15 \mathrm{~cm}$ in length, $0.46 \mathrm{~cm}$ inner diameter) column with a S5ODS2 safe-guard column (Waters, Milford, MA). Determinations of diadenosine polyphosphates and their hydrolysis products were carried out with paired-ion chromatography by gradient elution. Eluents $A$ and $B$ used for gradient elution were: $4 \mathrm{mmol}$ tetrabutylammonium hydrogen sulphate $\mathrm{I}^{-1}$ in $20 \mathrm{mmol}$ $\mathrm{KH}_{2} \mathrm{PO}_{4} \mathrm{I}^{-1}, \mathrm{pH} 6.0$ (Eluent $\mathrm{A}$ ) and Eluent $\mathrm{A}+12 \%(\mathrm{v} / \mathrm{v})$ acetonitrile, pH 7.4 (Eluent B). Diadenosine polyphosphates and their degradation products were eluted with the following gradient: $0-1 \mathrm{~min}, 30 \% \mathrm{~B} ; 2.0$ $10.5 \mathrm{~min}, 60 \% \mathrm{~B} ; 4.5 \mathrm{~min}, 100 \% \mathrm{~B} ; 20 \mathrm{~min}, 100 \% \mathrm{~B}$; $1.5 \mathrm{~min}, 30 \% \mathrm{~B} ; 15 \mathrm{~min}, 30 \% \mathrm{~B}$. The column eluate was monitored at $254 \mathrm{~nm}$. Data were analysed by TurboChrom software (Perkin-Elmer, PE Nelson, San Jose, CA).

\section{Ecto-enzyme activities}

Enzyme activities capable of hydrolysing diadenosine compounds, nucleoside mono-, di-, and triphosphates, 
and of deaminating adenosine were assayed with HPLC by measuring the residual amount of substrate concentration. One unit of enzyme activity was defined as the amount of enzyme that degrades $1 \mathrm{nmol} \mathrm{min}{ }^{-1}$. Aminopeptidase was assayed according to Laurell et al. (1982) and one unit of enzyme activity was defined as the amount of enzyme that degrades $0.1 \mathrm{nmol} \mathrm{min}^{-1}$. Alkaline phosphatase was assayed according to Cox et al. (1967) and one unit of enzyme activity was defined as the amount of enzyme that degrades $1 \mathrm{nmol} \mathrm{min}^{-1}$.

\section{Determination of Ap3/4A hydrolase activity}

Ap3/4A hydrolase activity was measured by determining the residual amount of substrate using HPLC. Vesicles $(5 \mu \mathrm{g})$ were incubated at $37^{\circ} \mathrm{C}$ in $20 \mathrm{mmol}$ Hepes $\mathrm{I}^{-1}$, $2 \mathrm{mmol} \mathrm{MgCl}_{2} \mathrm{I}^{-1}$ and $2 \mathrm{mmol} \mathrm{CaCl} \mathrm{I}^{-1}, \mathrm{pH} 7.4$, for $3 \mathrm{~min}$ in the presence of $500 \mu \mathrm{mol}$ substrate $\mathrm{I}^{-1}$. Samples were then filtered through RC $0.2 \mu \mathrm{m}$ Corning filters and run as described above. Controls without the addition of vesicles were included in each experiment to measure the non-enzymatic hydrolysis of the substrate. The initial velocity was constant and indicated that $<10 \%$ of the substrate was hydrolysed. The effect of cations was investigated by performing the experiments in the absence of $2 \mathrm{mmol} \mathrm{MgCl} \mathrm{I}^{-1}$ and $2 \mathrm{mmol} \mathrm{CaCl} \mathrm{I}^{-1}$. Suramin was used at a concentration of $100 \mu \mathrm{mol} \mathrm{I}^{-1}$ and the vesicles were pre-incubated $1 \mathrm{~h}$ before the addition of the substrates. All the determinations were carried out in triplicate and activities were expressed as $\mathrm{U} \mathrm{mg}^{-1}$ protein. Determinations of ecto-nucleotidases and adenosine deaminase activities were performed as described for diadenosine hydrolysing activity. Studies of the degradation of $\mathrm{Ap} 3 / 4 \mathrm{~A}$ by rabbit seminal fluid vesicles $(50 \mu \mathrm{g})$ were performed by incubating $500 \mu \mathrm{mol}$ substrate $\mathrm{I}^{-1}$ in a final volume of $1.0 \mathrm{ml}$ in $20 \mathrm{mmol}$ Hepes $\mathrm{I}^{-1}, 2 \mathrm{mmol} \mathrm{MgCl}_{2} \mathrm{I}^{-1}$ and $2 \mathrm{mmol} \mathrm{CaCl} \mathrm{I}^{-1}, \mathrm{pH} 7.4$, at $37^{\circ} \mathrm{C}$. At fixed intervals, aliquots were withdrawn, filtered through RC $0.2 \mu \mathrm{m}$ Corning filters and run as described above. Studies of the degradation of Ap3/4A by rabbit seminal fluid vesicles $(50 \mu \mathrm{g})$ in the presence of rabbit spermatozoa $\left(5 \times 10^{6}\right.$ cells) were performed by incubating substrate, vesicles and spermatozoa in the presence of $10 \mu \mathrm{mol}$ dipyridamole $\mathrm{I}^{-1}$, an inhibitor of nucleoside transport. Experiments were carried out as described above.

\section{Phospholipase C treatment}

The anchorage of ApnA hydrolysing enzyme to vesicle membranes was investigated by treating rabbit seminal fluid vesicles with phosphatidylinositol-specific phospholipase from B. cereus, according to RodriguezPascual et al. (1992). Membrane vesicles $(100 \mu \mathrm{g})$ were treated with 1.0 iu PI-PLC in a final volume of $0.5 \mathrm{ml}$ of $50.0 \mathrm{mmol}$ Hepes $\mathrm{I}^{-1}, \mathrm{pH} 7.4$, for $2 \mathrm{~h}$. The suspension was centrifuged at $105000 \mathrm{~g}$ for $60 \mathrm{~min}$ at $4{ }^{\circ} \mathrm{C}$ and the pellet, suspended in $50 \mathrm{mmol}$ Hepes $\mathrm{I}^{-1}, \mathrm{pH} 7.4$, was used to investigate Ap3A hydrolase activity as described above. Control experiments were performed with vesicles incubated for $1 \mathrm{~h}$ at $4{ }^{\circ} \mathrm{C}$ in the absence of PI-PLC.

\section{Assessment of capacitation}

Spermatozoa were assayed for capacitation by induction of acrosome reaction with $100 \mu \mathrm{mol} L-\alpha-$ lysophosphatidylcholine (LPC) $\mathrm{I}^{-1}$ (de Lamirande et al., 2002; Tundathil et al., 2002). LPC was previously shown to induce the acrosome reaction in capacitated spermatozoa, but it had no effects on uncapacitated spermatozoa (Parrish et al., 1988). Spermatozoa (10 × $10^{6}$ ) were incubated for $30 \mathrm{~min}$ in Tyrode's albumin lactate pyruvate (TALP) $\left(100.0 \mathrm{mmol} \mathrm{NaCl}{ }^{-1}, 3.0 \mathrm{mmol}\right.$ $\mathrm{KCl} \mathrm{I}{ }^{-1}, 0.4 \mathrm{mmol} \mathrm{MgCl}_{2} \mathrm{I}^{-1}, 0.3 \mathrm{mmol} \mathrm{Na}_{2} \mathrm{HPO}_{4} \mathrm{I}^{-1}$, $24.0 \mathrm{mmol} \mathrm{NaHCO}_{3} \mathrm{I}^{-1}, 0.2 \mathrm{mmol}$ sodium pyruvate

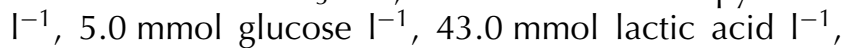
$1.0 \mathrm{mmol}$ Hepes $\mathrm{I}^{-1}, 50 \mathrm{mg}$ streptomycin $\mathrm{I}^{-1}$ and $50 \times$ $10^{3} \mathrm{U}$ penicillin $\mathrm{I}^{-1}, \mathrm{pH} 7.4$ ) at $37^{\circ} \mathrm{C}$ in $5 \% \mathrm{CO}_{2}$ and $95 \%$ humidified air to induce acrosome reaction with LPC. At the end of the incubation period, $100 \mu \mathrm{mol}$ LPC I ${ }^{-1}$ was added and the spermatozoa were incubated for an additional $15 \mathrm{~min}$. Before drying and staining, randomly selected slides containing approximately $10^{5}$ cells were examined to verify motility and viability of sperm cells. The percentage of spermatozoa that were acrosome-reacted was determined on air-dried spermatozoa smears with Pisum sativum agglutinin fluorescein isothiocyanate (PSA-FITC) conjugated staining (Mendoza et al., 1992). At least 200 cells were scored with an Axioplan Zeiss epifluorescence microscope equipped with a 390-525 nm filter (Gottingen) according to the following patterns: (i) selective staining of the whole acrosome (unreacted cells); and (ii) no staining or limited to the equatorial segments (reacted cells). In experiments performed to determine whether seminal fluid vesicles and diadenosine polyphosphates had a capacitative effect on uncapacitated spermatozoa, the protocol was modified by substituting BSA with vesicles and diadenosine polyphosphates previously incubated for $2 \mathrm{~h}$. The capacitative status was assayed by induction of acrosome reaction with LPC and the capacitative effects were evaluated by comparing the rate of acrosome reaction promoted by LPC in the control (TALP plus $0.3 \% \mathrm{BSA}$ ) and in the experimental conditions (TALP plus vesicles and diadenosine compounds previously incubated for $2 \mathrm{~h}$ at $37^{\circ} \mathrm{C}$ ).

In experiments performed to determine whether seminal fluid vesicles and diadenosine compounds can act as acrosome reaction initiators, LPC was substituted by vesicles and diadenosine compounds previously incubated for $2 \mathrm{~h}$. Spermatozoa were capacitated in TALP-BSA as described above. At the end of the 


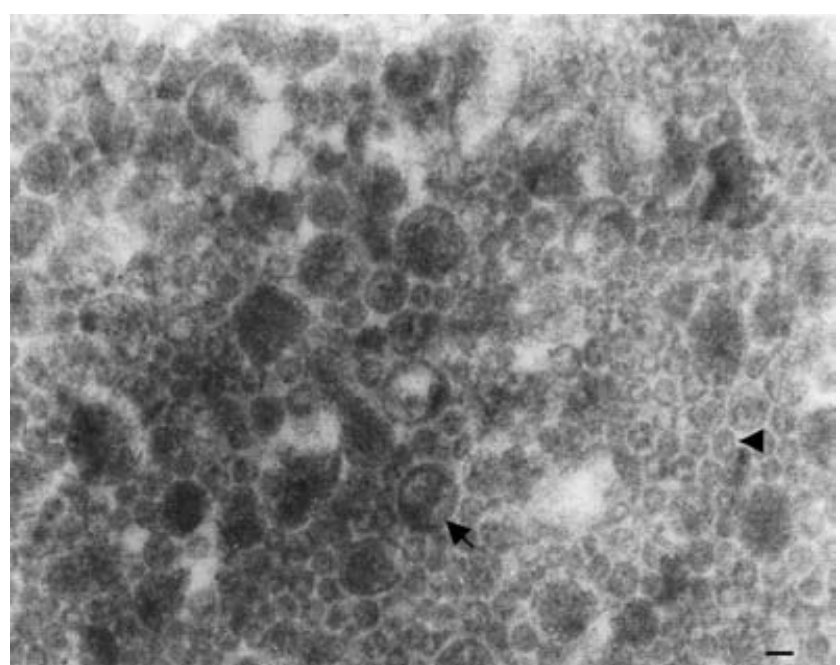

Fig. 1. Electron microscopy of isolated vesicles from rabbit seminal fluid. Vesicles were isolated and fixed in $\mathrm{OsO}_{4}$. Arrow: large vesicles; arrowhead: small vesicles. Scale bar represents $70 \mathrm{~nm}$.

incubation, the effectors were added and incubation continued for a further $15 \mathrm{~min}$. Acrosome-reacted cells were evaluated by PSA-FITC staining. The ability of the effectors to induce acrosome reaction was expressed as the difference between the acrosome reaction rate promoted under the experimental conditions and the induced acrosome reaction rate observed in the control (TALP-BSA-LPC).

\section{Statistical analysis}

Data are expressed as means \pm SEM. Statistical significance was determined by using the Student's $t$ test and ANOVA. A $P$ value $<0.05$ was considered significant.

\section{Results}

\section{Electron microscope observations}

The pellet consisted mainly of numerous, small round vesicles with a diameter of about $70 \mathrm{~nm}$. The particles were surrounded by a bilaminar membrane and contained an amorphous matrix. Vesicles with a diameter of $>160 \mathrm{~nm}$ were also observed in the preparation (Fig. 1).

\section{Enzyme activities of rabbit seminal vesicles}

Enzyme activities were determined on isolated rabbit seminal fluid vesicles (Table 1). The hydrolysing activities towards ATP and ADP were very high, exceeding the hydrolysis of diadenosine compounds by $>1000$-fold. There was a low hydrolysing activity towards AMP that ranged in the same order of magnitude of adenosine deaminase activity. ApnA, ATP and ADP hydrolysing
Table 1. Enzyme activities of rabbit seminal vesicles

\begin{tabular}{lc}
\hline Enzyme & Activity $\left(\mathrm{U} \mathrm{mg}^{-1}\right.$ protein $)$ \\
\hline *ApnA hydrolase & $13.3 \pm 2.1$ \\
*ATPase & $16000 \pm 1500$ \\
*ADPase & $5000 \pm 1000$ \\
$5^{\prime}$ nucleotidase & $2.8 \pm 0.9$ \\
Adenosine deaminase & $1.4 \pm 1.1$ \\
Alkaline phosphatase & $262 \pm 8$ \\
Aminopeptidase & $<0.5$
\end{tabular}

*ApnA, ATP and ADP hydrolysis was inhibited by the omission in the reaction medium of $\mathrm{Ca}^{2+}-\mathrm{Mg}^{2+}(20 \%$ residual activity); the addition of $100 \mu \mathrm{mol}$ suramin $\mathrm{I}^{-1}$ did not cause significant inhibitions (95\% residual activity).

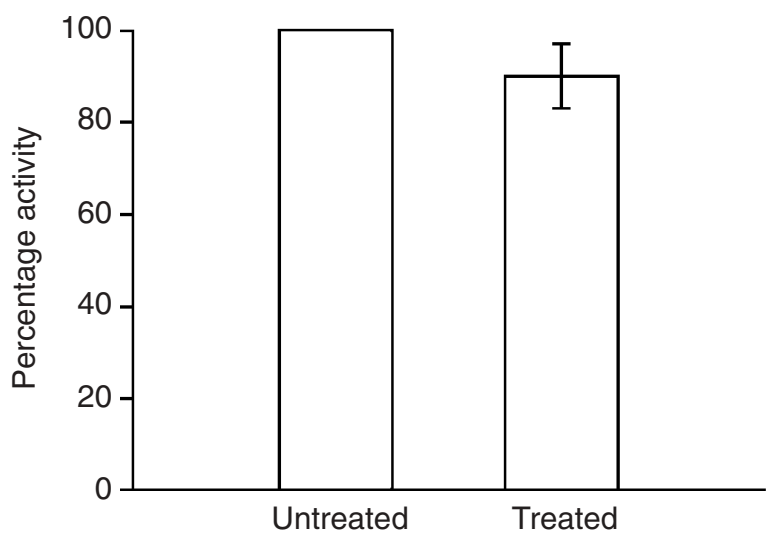

Fig. 2. Effect of phosphatidylinositol phospholipase $C$ on ectodiadenosine hydrolysing enzyme of rabbit seminal fluid vesicles. Vesicles $(100 \mu \mathrm{g})$ were treated with 1 iu PI-PLC as described. After $1 \mathrm{~h}$ of treatment, the residual enzyme activity on the vesicles was

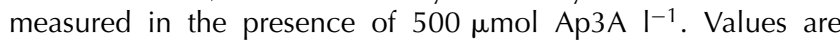
expressed as the percentage of the activity of control seminal fluid vesicles. The results are the means \pm SEM of four separate experiments performed in triplicate.

activities were $\mathrm{Ca}^{2+}$ and $\mathrm{Mg}^{2+}$-dependent, whereas they were inhibited slightly by $100 \mu \mathrm{mol}$ suramin $\mathrm{I}^{-1}$. Alkaline phosphatase activity was $262 \mathrm{U}$ mg protein ${ }^{-1}$, whereas aminopeptidase, the marker enzyme of human prostasomes, was not present at the membrane of the vesicles.

\section{Effects of PI-PLC treatment on seminal vesicles ApnA hydrolytic activity}

Phosphatidyl inositol-specific phospholipase $C$ from $B$. cereus did not release the ecto-ApnA hydrolysing enzyme from rabbit vesicles. After $1 \mathrm{~h}$ of incubation with PI-PLC (1.0 iu ml-1), the capacity of vesicles to hydrolyse Ap3A was not significantly lower than that of the control (Fig. 2). Thus, the presence of a GPI-anchoring domain for the ecto-enzyme is ruled out. 

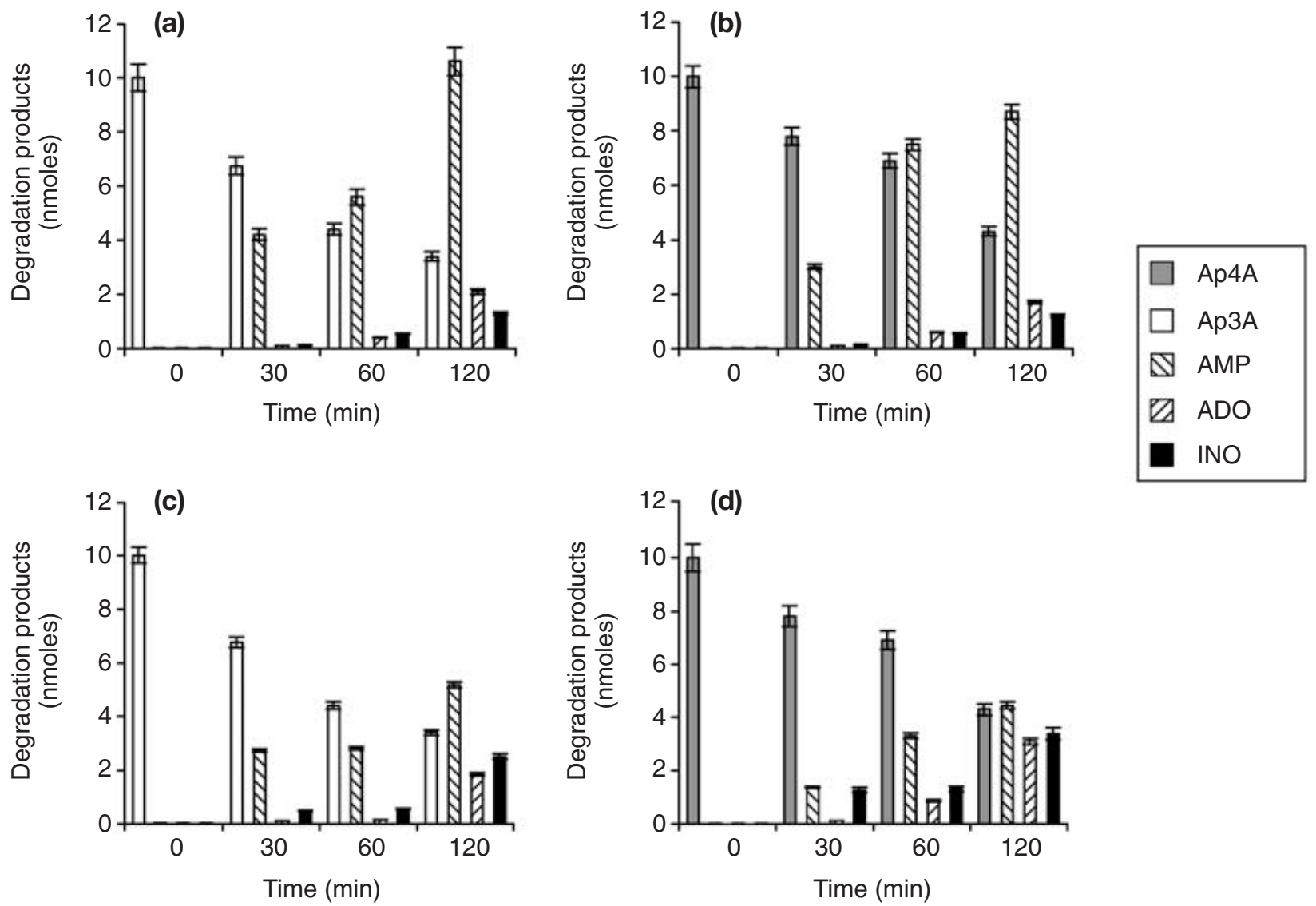

Fig. 3. Degradation pattern of diadenosine polyphosphates by rabbit seminal fluid vesicles $(a, b)$ in the absence and (c,d) in the

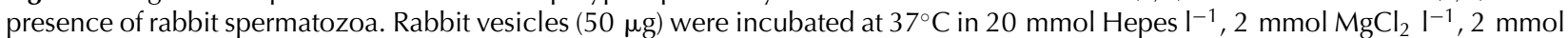

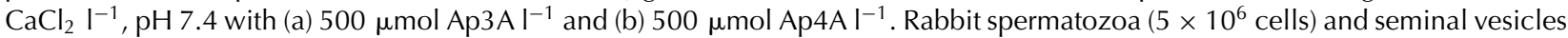

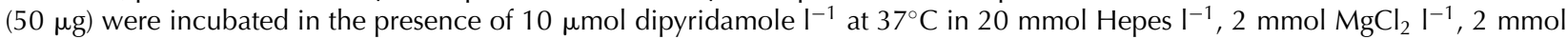

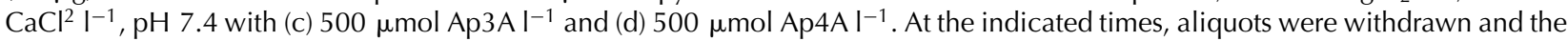
degradation products analysed by high performance liquid chromatography. ADO: adenosine; INO: inosine. The results represent the means \pm SEM of four separate experiments.

\section{Degradation pattern of diadenosine polyphosphate by rabbit seminal vesicles}

The HPLC studies showed that adenine dinucleotides are metabolized by rabbit seminal fluid vesicles. Representative time courses of hydrolysis of $500 \mu \mathrm{mol}$ ApnA I ${ }^{-1}$ are reported (Fig. 3) and provide insights into the diadenosine polyphosphates hydrolase mechanism. AMP is the main product of the asymmetrical degradation that splits the diadenosine triphosphates into AMP and ADP. After $120 \mathrm{~min}$ of incubation, AMP concentration was almost twice that of the degraded Ap3A, indicating that ADP contributes to the concentration of AMP. During the observations, ADP was not detected. This finding indicates that ectoADPase is very active and acts with no time-lag. Only a small portion of AMP was further degraded to adenosine which, in turn, was slowly deaminated into inosine. The absence of adenosine as the by-product indicates that the ecto-nucleotidase system that catalyses the sequential degradation of ATP to adenosine is not present on the entire surface of the rabbit vesicles. The compound was asymmetrically split into AMP and ATP, but the main degradative product was still AMP. Neither ATP nor ADP was detected during the observation, indicating a very high activity of ATPase as well as ADPase. The low concentrations of adenosine and inosine are consistent with enzyme determinations and indicate that ecto5 'nucleotidase and ecto-adenosine deaminase, although present at the surface of the rabbit seminal fluid vesicles, have a low enzyme activity.

The same degradations were performed in the presence of rabbit spermatozoa and dipyridamole, as an inhibitor of the adenosine up-take by sperm cells. AMP was still the main product of degradation but its concentration was markedly reduced by the action of spermatozoa 5'nucleotidase. However, the concentration of adenosine does not increase as it is deaminated to inosine. Nearly $60 \%$ of Ap4A was degraded to AMP, adenosine and inosine. AMP is 
(a)

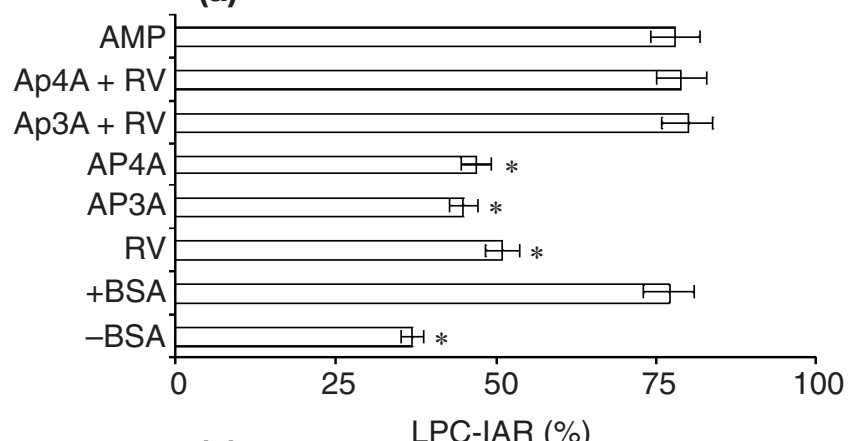

(b)

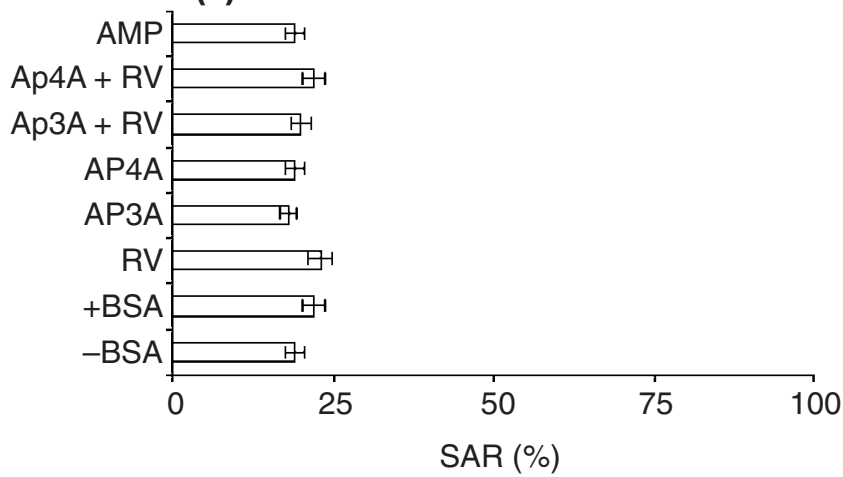

Fig. 4. Effect of seminal fluid vesicles and diadenosine compounds on uncapacitated rabbit spermatozoa. Pooled rabbit spermatozoa were incubated for $30 \mathrm{~min}$ at $37^{\circ} \mathrm{C}$ in $5 \% \mathrm{CO}_{2}$ in Tyrode's albumin lactate pyruvate containing $0.3 \% \mathrm{BSA}, 500 \mu \mathrm{mol} \mathrm{Ap}^{\mathrm{A}} \mathrm{I}^{-1}$, $500 \mu \mathrm{mol} A p 4 \mathrm{~A} \mathrm{I}^{-1}, 50 \mu \mathrm{g}$ rabbit vesicles (RV), $2 \mathrm{~h}$ pre-incubated $500 \mu \mathrm{mol}$ Ap3 A I ${ }^{-1}+50 \mu \mathrm{g} \mathrm{RV}, 2 \mathrm{~h}$ pre-incubated $500 \mu \mathrm{mol}$ Ap4 $\mathrm{Al}^{-1}+50 \mu \mathrm{g}$ RV and $250 \mu \mathrm{mol} \mathrm{AMP} \mathrm{I}{ }^{-1}$. Acrosome reaction was induced by L- $\alpha$-lysophosphatidylcholine (LPC) $\left(100 \mu \mathrm{mol} \mathrm{I}^{-1}\right.$ for $15 \mathrm{~min}$ at $37^{\circ} \mathrm{C}$ ). Acrosome-reacted cells were determined by Pisum sativum-fluorescein isothiocyanate. The results represent the mean \pm SEM of $n=5$ independent experiments performed in triplicate and 200 spermatozoa counted per sample. Significant differences versus control (BSA-LPC), $* P<0.05$. (a) Capacitative status of the spermatozoa evaluated with LPC-induced acrosome reaction (IAR); (b) percentage of spontaneous acrosome reaction (SAR) of the samples after 30 min incubation under the described experimental conditions.

the main by-product, but its concentration is reduced by spermatozoa 5 'nucleotidase. The concentration of adenosine is consequently increased, although this increase does not fully account for the degraded AMP, as adenosine is further deaminated to inosine.

\section{Effects of seminal fluid vesicles and diadenosine compounds on capacitation and acrosome reaction}

The effects of seminal fluid vesicles and diadenosine compounds on uncapacitated rabbit spermatozoa were investigated by substituting BSA with vesicles, diadenosine compounds, AMP, and vesicles and diadenosine compounds after a $2 \mathrm{~h}$ incubation at $37^{\circ} \mathrm{C}$ in the capacitative medium (TALP-BSA) (Fig. 4). Capacitation

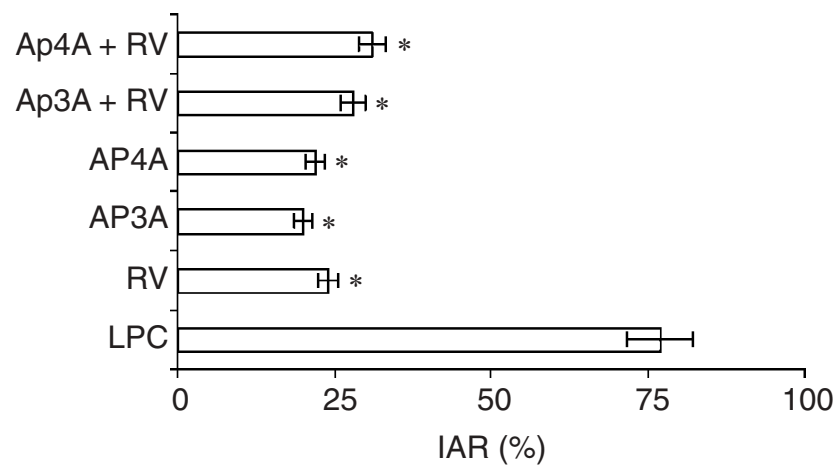

Fig. 5. Effect of seminal fluid vesicles and diadenosine compounds on capacitated rabbit spermatozoa. Capacitated rabbit spermatozoa (30 min in Tyrode's albumin lactate pyruvate-BSA at $37^{\circ} \mathrm{C}$ in $\mathrm{CO}_{2}$ ) were incubated at $37^{\circ} \mathrm{C}$ for $15 \mathrm{~min}$ with:

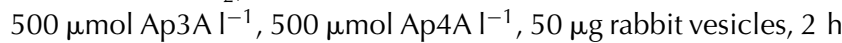

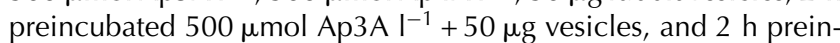

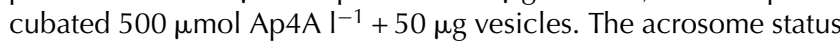
was determined by Pisum sativum-fluorescein isothiocyanate and

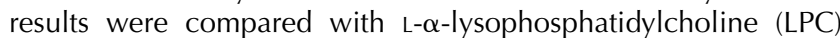
acrosome reaction of the control. IAR: induced acrosome reaction. The results represent the mean \pm SEM of $n=5$ independent experiments performed in triplicate and 200 spermatozoa were counted per sample. Significant differences versus induced acrosome-reacted control (BSA-LPC), ${ }^{*} P<0.05$.

was measured by the ability of the sperm cells to undergo the acrosome reaction when LPC, the inducer of acrosome reaction, was added to the suspension. Pooled sperm samples used in the present study were characterized by $22 \pm 6 \%$ of spontaneous acrosome reaction after $30 \mathrm{~min}$ of incubation in TALP-BSA at $37^{\circ} \mathrm{C}$ in $5 \% \mathrm{CO}_{2}$ and by $77 \pm 6 \%$ induced acrosome reaction after 15 min of treatment with $100 \mu \mathrm{mol}$ LPC $\mathrm{I}^{-1}$. The percentage of capacitated spermatozoa was $55 \pm 6 \%$. The substitution of BSA with diadenosine compounds and vesicles after $2 \mathrm{~h}$ of incubation in the capacitative medium did not diminish the capacitative status of rabbit spermatozoa. The percentage of LPCreacted cells was not significantly different from the control, indicating that the products of degradation of diadenosine compounds by seminal fluid vesicles and spermatozoa can exert a capacitative effect. Indeed, the incubation of rabbit sperm cells in the presence of AMP resulted in an LPC-induced acrosome reaction rate that was not significantly different from those obtained with diadenosine compounds and vesicles after $2 \mathrm{~h}$ of incubation. In the presence of either diadenosine compounds or vesicles, the percentage of LPC induced-acrosome reaction in rabbit spermatozoa was significantly lower than that obtained in the presence of BSA. Under all the experimental conditions, the percentage of cells that underwent the spontaneous acrosome reaction was not significantly modified. The effects of seminal fluid vesicles and diadenosine compounds on BSA-capacitated rabbit spermatozoa are shown (Fig. 5). Diadenosine 
compounds, after a $2 \mathrm{~h}$ incubation with vesicles, were ineffective at inducing the acrosome reaction. The rate of acrosome reaction was significantly lower than the LPCinduced acrosome reaction. The percentage of induced acrosome reaction was not significantly different from the rate of spontaneous acrosome reaction. Neither vesicles alone nor diadenosine compounds alone could induce the acrosome reaction.

\section{Discussion}

The presence of membrane vesicles in rabbit seminal plasma has been investigated previously. The present study describes a protocol for isolating the vesicles which is less time consuming than the procedure described by Davis (1973).

The membrane vesicles in seminal plasma in different species differ not only in their site of origin, but also in their biochemical composition. Bovine vesiculosomes contain aminopeptidase A (Agrawal and Vanha-Pertulla, 1985) and alanyl-aminopeptidase (Agrawal and VanhaPertulla, 1986a,b). In addition, the particles demonstrate Mg-Ca-ATPase, $\alpha$-glutamyl transpeptidase and dipeptidyl peptidase IV activities, which are all well known membrane-bound enzymes in cells and tissues (Agrawal and Vanha-Pertulla, 1987). Endopeptidase activity that hydrolyses Succ (Ala)3-pNA is a marker for human and equine prostasomes, but it is not present in rabbit vesicles. The lack of this enzyme activity also characterizes bovine vesiculosomes (Agrawal and Vanha-Pertulla, 1986b). Therefore, the non-prostatic origin of rabbit vesicles seems to be supported. Ectonucleotidases are surprisingly very active at the surface of the vesicles in rabbit seminal fluid, showing a rapid degradation of ATP into AMP. The time course of diadenosine polyphosphates and the time-dependent generation of dephosphorylated products show that neither ATP nor ADP accumulate in the assay medium. The hydrolysis proceeds directly to AMP which, in turn, accumulates in the medium because of the lack of ecto-nucleoside $5^{\prime}$ monophosphate activity. This pattern of degradation is not compatible with the presence of unspecified ecto-nucleotidases in which ATP is sequentially degraded to AMP with the formation of ADP as an intermediate product (Zimmermann, 1996a,b). It has been shown that only ecto-apyrase (ecto-ATP diphosphohydrolase) can account for this pattern (Heine et al., 1999). Ecto-enzyme of rabbit vesicles is also activated by cations and not inhibited by suramin, as reported for ecto-apyrase (Heine et al., 1999). In contrast, suramin is a strong inhibitor of ecto-ATPase from chicken gizzard (Caldwell et al., 2001) and for ecto-diadenosine polyphosphate hydrolase (Mateo et al., 1996). PLC treatment of rabbit vesicles showed that the ecto-enzyme is not GPI-anchored to the membrane, in contrast to other findings on diadenosine polyphosphate hydrolase (Rodriguez-Pascual et al., 1992; Minelli et al.,
2002). Therefore, it was proposed that the ecto-enzyme of rabbit seminal fluid vesicles is an ecto-apyrase capable of degrading diadenosine polyphosphate compounds. These results are in contrast to findings reported by Minelli et al., (2002) on human prostasomes, in which prostasomes were shown to have diadenosine polyphosphate hydrolase activity and the ecto-nucleotidase cascade responsible for exhaustive degradation of ATP into adenosine. Therefore, the addition of ApnA to prostasomes produces a fairly high amount of adenosine. Rabbit vesicles are provided with an enzyme activity that hydrolyses diadenosine compounds, ATP and ADP but, because of the lack of $5^{\prime}$ nucleotidase activity, the addition of Ap3/4A to the vesicles does not lead to marked production of adenosine. Adenosine is produced only when the degradation of diadenosine compounds occurs in the presence of rabbit spermatozoa. 5'nucleotidase is localized to the membrane of mammalian spermatozoa (Minelli et al., 1995) and the ecto-enzyme is responsible for the adenosine production observed in the present experimental conditions. The results obtained by chromatography show that $A p 4 A$ is degraded by rabbit vesicles to a lesser extent than Ap3A and that AMP is the by-product. When the degradation of $\mathrm{Ap} 4 \mathrm{~A}$ and $\mathrm{Ap} 3 \mathrm{~A}$ are carried out in the presence of rabbit spermatozoa, adenosine and inosine are detected. In addition to 5'nucleotidase, sperm cells have adenosine deaminase (Minelli et al., 1999), which transforms adenosine into inosine. Therefore, although the degradation of diadenosine compounds is exhaustive under these experimental conditions, adenosine production is lower than that produced by human prostasomes (Minelli et al., 2002). The presence of diadenosine hydrolytic activity on prostasomes (Minelli et al., 2002) raises a new possibility for the physiological role of diadenosine compounds and prostasomes. Mammalian extracellular vesicles are involved in several physiological roles and exert opposing effects in the fertilization process. In bulls and humans, they promote forward sperm motility and induce the acrosome reaction (Agrawal and Vanha-Pertulla, 1987), whereas in rabbits they have been reported to inhibit fertilization (Davis and Hungund, 1976). The results of the present study of the effects of vesicles and diadenosine compounds on the capacitation and acrosome reaction of rabbit spermatozoa show that after a $2 \mathrm{~h}$ incubation with seminal vesicles, diadenosine compounds can efficiently substitute BSA as a capacitating effector, indicating that the products of degradation of diadenosine compounds can replace BSA in the capacitating medium. It is known that an increase in the rate of spontaneous acrosome reaction is detrimental to the potential fertilizing capacity of ejaculated spermatozoa and the results of the present study have shown that vesicles and degradation products of diadenosine compounds do not increase this rate. A membrane associated phenomenon by which seminal fluid vesicles stabilize sperm cell membranes 
thus preventing pre-fertilization acrosome reaction, as suggested by Davis (1973), might be responsible for this low spontaneous acrosome reaction rate. The addition of vesicles and diadenosine compounds to capacitated rabbit spermatozoa does not act as an inducer of acrosome reaction, indicating that vesicles and diadenosine compounds separately or diadenosine degradation products cannot act as inducers of acrosome reaction.

In conclusion, the results of the present study in vitro show that diadenosine compounds, ATP and ADP can be degraded into AMP by hydrolytic activity of the rabbit vesicles and that AMP is further hydrolysed into adenosine by spermatozoa ecto-5'nucleotidase. In addition, the results are indicative of a capacitative effect of seminal fluid vesicles and diadenosine compounds previously incubated for $2 \mathrm{~h}$ at $37^{\circ} \mathrm{C}$. Minelli et al. (2000) proposed that the capacitative effect of the degradation products of diadenosine compounds might be related to adenosine acting on the adenosine receptors present on the surface of rabbit sperm cells. Allegrucci et al. (2001) showed that the stimulation of A1 adenosine receptors has beneficial effects on fertilization as it enhances capacitation allowing the acrosome reaction, a fundamental step in the fertilization of the oocyte. Membrane vesicles in rabbit seminal fluid degrade nucleoside di- and triphosphates present in seminal plasma, providing a large amount of substrate to spermatozoa 5'nucleotidase which, in turn, produces adenosine. Results obtained in the presence of AMP in the capacitative medium seem to support this proposal. Diadenosine compounds, at present not detected in rabbit seminal plasma, might be present in the female reproductive tract where the hydrolytic activity of the vesicles could increase the amount of AMP that rabbit spermatozoa will transform into extracellular adenosine with its beneficial effects on the fertilization process.

The authors thank M. Kerrigan, MA (Cantab) for valuable linguistic suggestions. The research was funded by COFIN-MURST, Italy.

\section{References}

Agrawal Y and Vanha-Pertulla T (1985) Variable distribution of aminopeptidase $\mathrm{A}$ in male reproductive organs of mammals International Journal of Andrology $8243-256$

Agrawal Y and Vanha-Pertulla T (1986a) Studies on the multiple forms of aminopeptidase A in bovine seminal vesicles secretion International Journal of Biochemistry 18 465-471

Agrawal Y and Vanha-Pertulla T (1986b) Alanyl aminopeptidase of bovine seminal vesicles secretion International Journal of Biochemistry 18725 729

Agrawal Y and Vanha-Pertulla T (1987) Effect of secretory particles in bovine seminal vesicle secretion on sperm motility and acrosome reaction Journal of Reproduction and Fertility 79 409-419

Allegrucci C, Liguori L and Minelli A (2001) Stimulation by N6cyclopentyladenosine of A1 adenosine receptors, coupled to Gai2 protein subunit, has a capacitative effect on human spermatozoa Biology of Reproduction 64 1653-1659
Arienti G, Polci A, Carlini E and Palmerini CA (1997) Transfer of CD26/dipeptydilpeptidase IV from prostasomes to sperm FEBS Letters $410343-346$

Breitbart A and Rubinstain S (1982) Characterization of Mg- and Ca-ATPase activity in membrane vesicles from ejaculated ram seminal plasma Archives of Andrology 9 147-157

Caldwell CC, Hornyak SC, Pendleton E, Campbell D and Knowles AF (2001) Regulation of chicken gizzard ecto-ATPase activity by modulators that affect its oligomerization status Archives of Biochemistry and Biophysics 387 107-116

Carlsson L, Pahlson C, Bergquist M, Ronquist G and Stridsberg M (2000a) Antibacterial activity of human prostasomes Prostate $\mathbf{4 4} 279-286$

Carlsson L, Lennartsson L, Nilsson S and Ronquist G (2000b) Growthinhibitory effect of prostasomes on prostatic cancer cell lines in culture European Urology 38 468-474

Cartwright JL and McLennan AG (1999) The Saccharomyces cerevisiae YOR163w gene encodes a diadenosine $5^{\prime}, 5^{\prime \prime \prime} \mathrm{P} 1, \mathrm{P} 6$-hexaphosphate (Ap6A) hydrolase member of the MutT motif (Nudix hydrolase) family Journal of Biological Chemistry 274 8604-8610

Chan PJ, Su BC and Tredway DR (1991) Diadenosine tetraphosphate (Ap4A) and triphosphate (Ap3A) signaling of human sperm motility Archives of Andrology 27 103-108

Cox RP, Gilbert P, Jr and Griffin MJ (1967) Alkaline inorganic pyrophosphatase activity of mammalian cell alkaline phosphatase Biochemistry Journal 105 155-161

Davis BK (1973) Occurrence of vesicles in rabbit seminal plasma Experientia 29 1484-1487

Davis BK and Hungund BJ (1976) Effect of modified membrane vesicles from seminal plasma on the fertilizing capacity of rabbit spermatozoa Biochemistry and Biophysics Research Communication 69 1004-1010

de Lamirande E and Gagnon C (2002) The extracellular signal-regulated kinase (ERK) pathway is involved in human sperm function and modulated by the superoxide anion Molecular Human Reproduction 8 124-135

Edgecombe M, McLennan AG and Fisher MJ (1996) Characterization of the binding of diadenosine $5^{\prime}, 5^{\prime \prime \prime} \mathrm{P} 1, \mathrm{P} 4$-tetraphosphate (Ap4A) to rat liver cell membranes Biochemical Journal 314 687-693

Fabiani R and Ronquist G (1995) Association of some hydrolytic enzymes with the prostasome membrane and their differential responses to detergent and PI-PLC treatment Prostate 27 95-101

Fornes MW, Barbieri A, Sosa MA and Bertini F (1991) First observation on enzyme activity and protein content of vesicles separated from rat epididymal fluid Andrologia 23 347-351

Goldman SJ, Gordon EL and Slakey LL (1980) Hydrolysis of diadenosine $5^{\prime}, 5^{\prime \prime \prime} \mathrm{P} 1, \mathrm{P} 3$-triphosphate (Ap3A) by porcine aortic endothelial cells Circulation Research 59 362-366

Heine P, Braun N, Heilbronn A and Zimmermann H (1999) Functional characterization of rat ecto-ATPase and ecto-ATP diphosphohydrolase after heterologous expression in $\mathrm{CHO}$ cells European Journal of Biochemistry 262 102-107

Hoyle CHV, Pintor J, Gualix J and Miras Portugal MT (1997) Antagonism of $\mathrm{P} 2 \mathrm{X}$ receptors in guinea pig vas deferens by diadenosine pentaphosphates European Journal of Pharmacology 333 R1-R2

Ingram SW, Scott AS and Barnes LD (1999) Schizosaccharomyces pombe Aps1, a diadenosine $5^{\prime}, 5^{\prime \prime \prime} \mathrm{P} 1, \mathrm{P} 6$-hexaphosphate hydrolase that is a member of the Nudix (MutT) family of hydrolase: cloning of the gene and characterization of the purified enzyme Biochemistry $\mathbf{3 8}$ 3649-3655

Jimenez Al, Castro E, Delicado EG and Miras Portugal MT (1998) Potentiation of ATP calcium response by diadenosine pentaphosphates in individual cerebellar astrocytes Neuroscience Letters 246 1-3

Kelly RW (1995) Immunosuppressive mechanism in semen: implications for contraception Human Reproduction 10 1686-1693

Kisselev LL, Justesen J, Wolfson AD and Frolova LY (1998) Diadenosine oligophosphates $(A p(n) A)$, a novel class of signaling molecules FEBS Letters 427 157-163

Laurell CB, Weiber H, Ohlsson K and Rannevik G (1982) A Zn-dependent peptidase in prostatic organelles present in seminal plasma Clinica Chimica Acta 126 161-170 
McLennan AG (1992) Ap4A and other dinucleoside polyphosphates. CRC Press, Boca Raton, FL

Mateo J, Miras Portugal MT and Castro E (1996) Coexistence of P2Y-PPADSinsensitive PU2-purinoreceptors in endothelial cells from adrenal medulla British Journal of Pharmacology 119 1223-1232

Mateo J, Miras Portugal MT and Rotllan P (1997) Ectoenzymatic hydrolysis of diadenosine polyphosphates by cultured adrenomedullary vascular endothelial cells American Journal of Physiology 273 C918-C927

Mendoza C, Carreras A, Moos J and Tesarik J (1992) Distinction between true acrosome reaction and degenerative acrosome loss by a one-step method using Pisum sativum agglutinin Journal of Reproduction and Fertility 95 755-763

Minelli A, Miscetti P, Proietti A, Luzi L and Mezzasoma I (1995) Adenosine triphosphate catabolism in bovine spermatozoa Comparative Biochemistry Physiology 110 605-611

Minelli A, Moroni M, Martinez E, Mezzasoma I and Ronquist G (1998) Occurrence of prostasome-like membrane vesicles in equine seminal plasma Journal of Reproduction and Fertility $114237-243$

Minelli A, Allegrucci C, Mezzasoma I, Ronquist G, Lluis C and Franco $\mathbf{R}$ (1999) CD26 and adenosine deaminase interaction: its role in the fusion between horse membrane vesicles and spermatozoa Biology of Reproduction $\mathbf{6 1} 802-808$

Minelli A, Allegrucci C, Piomboni P, Manucci R, Lluis $\mathbf{C}$ and Franco $\mathbf{R}$ (2000) Immunolocalization of A1 adenosine receptors in mammalian spermatozoa Journal of Histochemistry and Cytochemistry 48 11631171

Minelli A, Allegrucci C, Liguori L and Ronquist G (2002) Ecto-diadenosine polyphosphates hydrolase activity on human prostasomes Prostate $\mathbf{5 1}$ $1-10$

Miras Portugal MT, Gualix J and Pintor J (1998) The neurotransmitter role of diadenosine polyphosphates FEBS Letters 430 78-82

Miras Portugal MT, Gualix J, Mateo J, Diaz-Hernandez M, GomezVillafuertes R, Castro E and Pintor J (1999) In Progress in Brain Research (Vol.120) pp 397-409 Eds P Illes and H Zimmerman. Elsevier Science BV

Nilsson BO, Jin M, Einasson B, Persson BE and Ronquist G (1998) Monoclonal antibodies against human prostasomes Prostate 35 178184

Ogilvie A, Luthje J, Pohl U and Busse R (1989) Identification and partial characterization of an adenosine 5-tetraphosphate 5-adenosine hydrolase on intact bovine aortic endothelial cells Biochemistry Journal 259 97-103

Olsson I and Ronqust G (1990) Isoenzyme pattern of lactate dehydrogenase associated with human prostasomes Urology International 451 346-349

Parrish JJ, Susko-Parrish J, Winer MA and First NL (1988) Capacitation of bovine sperm by heparin Biology of Reproduction 38 1171-1180

Pintor J, King BF, Miras Portugal MT and Burnstock G (1996) Selectivity and activity of adeninedinucleotide at recombinant $\mathrm{P} 2 \mathrm{X} 2$ and $\mathrm{P} 2 \mathrm{Y} 1$ purinoreceptors British Journal of Pharmacology 116 1618-1627

Pintor J, Carracedo G, Alonso MC, Bautista A and Peral A (2002) Presence of diadenosine polyphosphates in human tears Pflugers Archives $\mathbf{4 4 3}$ 432-436

Randerath K, Janeway CM, Stephenson ML and Zamecnik PC (1966) Isolation and characterization of dinucleoside tetra- and tri-phosphates formed in the presence of lysyl-sRNA synthetase Biochemistry and Biophysics Research Communication 24 98-105
Rodriguez-Pascual F, Torres M, Rotllan P and Miras Portugal MT (1992) Extracellular hydrolysis of diadenosine polyphosphates, ApnA, by bovine chromaffin cells in culture Archives of Biochemistry and Biophysics 297 176-183

Rodriguez-Pascual F, Cortes R, Torres M, Palacios IM and Miras Portugal MT (1997) Distribution of H3-diadenosine tetraphosphate binding sites in rat brain Neuroscience 77 247-255

Ronquist G and Brody I (1985) The prostasomes: its secretion and function in man Biochemica Biophysica Acta 822 203-218

Ronquist G, Brody I, Gottfries A and Stegmayr B (1978a) An Mg- and Ca-stimulated adenosine triphosphatase in human prostatic fluid Part I Andrologia 10 261-272

Ronquist G, Brody I, Gottfries A and Stegmayr B (1978b) A Mg- and Ca-stimulated adenosine triphosphatase in human prostatic fluid Part II Andrologia 10 427-433

Ronquist G, Frith G and Jonsson A (1988) Prostasome membrane-associated enzyme activities and sperm parameters in men attending an infertility clinic Urology International 43 193-196

Safrany ST, Ingram SW, Cartwright JL, Falck JR, McLennan AG, Barnes LD and Shean SB (1999) The diadenosine hexa-phosphates hydrolase from S. pombe and $S$. cerevisiae are homologues of the human diphosphoinositolpolyphosphate phosphohydrolase Journal of Biological Chemistry $27421735-21740$

Thundathil J, de Lamirande E and Gagnon C (2002) Different signal transduction pathways are involved during human sperm capacitation induced by biological and pharmacological agents Molecular Human Reproduction 8 811-816

Verspohl EJ and Johannwille B (1998) Diadenosine polyphosphates in insulin-secreting cells: interaction with specific receptors and degradation Diabetes 47 1727-1734

Verspohl EJ, Johannwille B, Kaiserling-Buddemeier I, Schulter $\mathbf{H}$ and Hageman J (1999) Diadenosine polyphosphates in cultured vascular smooth muscle cells and endothelium cells. Their interaction with specific receptors and degradation Journal of Pharmacy and Pharmacology 51 1175-1181

Walker J, Bossman P, Lackey BR, Zimmermann JK, Dimmick MA and Hilderman RH (1993) The adenosine 5',5'”P1,P4-tetraphosphate receptor is at the cell surface of heart cells Biochemistry 32 14 009-14 014

Wang J, Lundqvist $M$, Carlsson L, Nilsson $O$, Lundqvist $O$ and Ronquist G (2001) Prostasome-like granules from PC-3 prostate cancer cell line increase the motility of washed human spermatozoa and adhere to the sperm European Journal of Obstetrics and Gynecology and Reproductive Biology 96 88-97

Zimmerman H (1996a) Extracellular purine metabolism Drug Development Research 39 337-352

Zimmerman H (1996b) Biochemistry, localization and functional roles of ecto-nucleotidases in the nervous system Progress in Neurobiology 49 589-618

Received 26 September 2002.

First decision 28 November 2002.

Revised manuscript received 18 December 2002.

Accepted 24 February 2003. 